\title{
Hypovitaminosis D and adipose tissue - cause and effect relationships in obesity
}

\author{
Marta Pelczyńska', Teresa Grzelak', Marcelina Sperling ${ }^{1}$, Krystyna Czyżewska' \\ ${ }^{1}$ Division of Biology of Civilization-Linked Diseases, Department of Chemistry and Clinical Biochemistry, Poznan \\ University of Medical Sciences, Poland
}

Pelczyńska M, Grzelak T, Sperling M, Czyżewska K. Hypovitaminosis D and adipose tissue - cause and effect relationships in obesity. Ann Agric Environ Med. 2016; 23(3): 403-409. doi: 10.5604/12321966.1219177

\begin{abstract}
In recent years, attention has been focused on pleiotropic directions of effects exerted by vitamin D. Epidemiological data indicate that deficiency of vitamin D in various population groups represents an increasingly widespread phenomenon, while a decreased serum concentration of calcitriol correlates with manifestation of civilization-linked diseases, including visceral obesity. This study aims at a review and synthesis of data linked to relationships between lowered vitamin D concentrations in blood and manifestation of obesity, and potential mechanisms which affect the concentration of the vitamin in conditions of an excessive accumulation of adipose tissue. Several variables are distinguished which can affect the status of vitamin $\mathrm{D}$ in obesity, but the key role in this respect is ascribed to the metabolic activity of visceral adipose tissue. Among others, the activity favours sequestration and modulation of calcitriol turnover. On the other hand, the effects of vitamin D on the process of adipogenesis and its involvement in remodelling of adipose tissue are pointed out. Also, several factors of an environmental nature (e.g. time of year/day, dietetic supply of vitamin D), genetic nature (e.g. genetic polymorphisms) and other conditioning (e.g. coexisting diseases, age, content of melanin in skin) cannot be bypassed as they may affect the concentration of vitamin D. Nevertheless, it still remains unresolved to what extent hypovitaminosis D represents the cause and to which it is the effect of obesity.
\end{abstract}

Key words

vitamin $D$, adipose tissue, obesity

\section{INTRODUCTION}

Vitamin D represents a nutritive component indispensable for the maintenance of calcium-phosphate homeostasis and control of bone metabolism. The compound, classified as fatsoluble, was discovered in 1919, as a potential anti-rachitic factor [1]. Vitamin D may be present in a few forms. The first, calciferol (vitamin $\mathrm{D}_{1}$ ) is present mainly in cod-liver oil, the other, ergocalciferol (vitamin $\mathrm{D}_{2}$ ) is supplied with nutrients (plants and mushrooms), while the third and most common, cholecalciferol (vitamin $\mathrm{D}_{3}$ ) arises first of all due to dermal synthesis (with involvement of UV rays), and, in a small proportion, is supplied with food products, such as milk, butter, fish and some mushrooms [2].

In recent years, the intense development of molecular biology and diagnostic methods have resulted in the identification of receptors for the active form of vitamin D in organs and tissues which are not involved in control of mineral metabolism. Therefore, the vitamin was beginning to be ascribed to another, pleiotropic direction of activity [3]. In line with the recommendations of scientific research centres, including that of the Endocrine Society of 2011, it is accepted that the reference values of vitamin $\mathrm{D}$ concentration in blood should exceed $75 \mathrm{nmol} / \mathrm{L}$. The levels of $50-75 \mathrm{nmol} / \mathrm{L}$ point to decreased concentrations of the compound (an insufficient level or hypovitaminosis), while concentrations of vitamin $\mathrm{D}$ in blood below $50 \mathrm{nmol} / \mathrm{L}$, indicates deficiency of this vitamin [4].

Address for correspondence: Marta Pelczyńska, Division of Biology of CivilizationLinked Diseases, Department of Chemistry and Clinical Biochemistry, Poznan University of Medical Sciences, Poland

E-mail: mpelczynska@ump.edu.pl

Received: 17 February 2014; accepted: 03 November 2014
Deficit of calcitriol is thought to result in a number of negative consequences for health and are indicated to be correlated with manifestation of specific civilization-linked diseases, including obesity. In this scope a significant role is ascribed to visceral adipose tissue, thought to represent the largest in the body metabolically active organ with the capability to interact with vitamin D. However, neither the detailed causes of hypovitaminosis D in obese individuals, nor the primary etiology of the disturbance have been clarified or defined $[3,5]$.

This study presents a review and synthesis of data on relationships between lowered blood vitamin D levels and manifestation of obesity, and on potential mechanisms which affect levels of the vitamin in conditions of an excessive accumulation of adipose tissue.

Turnover and cellular mechanism of vitamin $\mathrm{D}$ activity. The term of vitamin $\mathrm{D}$ is ascribed to the molecule consisting of four carbon rings (A, B, C, D) with a lateral chain. Due to its open $\mathrm{B}$ ring, the vitamin is classified within the group of secosteroid compounds. A provitamin $\mathrm{D}_{2}$ involves ergosterol, while $\mathrm{D}_{3}$ involves a cholesterol derivative, 7-dehydrocholesterol. Endogenous synthesis of vitamin D takes place in cell membranes of keratinocytes as well as in dermal fibroblasts, in which the earlier mentioned 7-dehydrocholesterol undergoes a photolytic conversion to previtamin D, cholecalciferol. The process takes place with the involvement of sun UVB rays of 290-315 $\mathrm{nm}$ wavelengths, while the duration of transformation amounts to around 30 minutes. Previtamin $\mathrm{D}$ produced in the processes is sequentially released to intercellular spaces and to blood circulation [6].

Independently of the pathway (exo- or endogenous one) in which vitamin $\mathrm{D}$ is supplied to the body, its metabolic 
activation is necessary. Therefore, its double enzymatic hydroxylation is required, involving a substitution of hydroxy group to respective carbon atoms in the molecule of cholecalciferol. The site of the first hydroxylation involves mitochondrial fractions of hepatocytes, in which 25 -hydroxycholecalciferol $\left(25(\mathrm{OH}) \mathrm{D}_{3}\right.$, calcidiol) is formed with involvement of 25-hydroxylase, belonging to the group of enzymes of cytochrome P450. Calcidiol is the main metabolite of vitamin D present in the circulation, while its metabolic activity is slightly higher than that of cholecalciferol. At the subsequent stage of transformation, the second hydroxylation takes place, yielding the biologically-active form of vitamin D, i.e. 1,25-dihydroxycholecalciferol $\left(1,25(\mathrm{OH})_{2} \mathrm{D}_{3}\right.$, calcitriol). The process takes place in the proximal tubules of the nephron, and the enzyme responsible for the conversion is $1 a$-hydroxylase. It should be added that calcitriol, regarded as representing a vitamin D-related hormone, undergoes a specific feedback control: it is responsible for the synthesis of 24-hydroxylase, an enzyme produced in the liver which begins the catabolic pathway of vitamin $\mathrm{D}$, inactivating it to calcitriolic acid excreted with the bile $[6,7]$.

The process of hydroxylation with involvement of $1 \alpha$-hydroxylase takes place also in, i.a., the large intestine, skeletal system, lungs, parathyroids, pancreatic $\beta$-cells, lymphocytes, monocytes or adipocytes. An extrarenal synthesis of $1,25(\mathrm{OH})_{2} \mathrm{D}_{3}$ indicates the local needs of specific tissues and organs for the vitamin-related hormone, although its activity is assumed to be of a local character, auto- and paracrine production of calcitriol is linked to its ability to stimulate cell differentiation or its involvement in immunomodulatory processes. Disturbances in synthesis of the vitamin or its insufficient supply are regarded to be complicated by development of various diseases, including obesity [6].

Calcitriol interacts with target cells through a specific nuclear Vitamin D Receptor (nVDR) belonging to the family of steroid hormone-specific receptors, acting as ligandactivated transcription factors. The gene of VDR (Vitamin $\mathrm{D}$ Receptor) is located on the long arm of chromosome 12 and it encompasses several polymorphisms. VDR manifests a domain structure which, in its free form, is present exclusively in the cell nucleus, but after complexing with the ligand (through the domain E) manifests its ability to interacti with other transcription factors, such as coactivatory SRC1 protein, manifesting the character of histone acetylase. The protein is capable of altering DNA structure and, in this way, of activating the promoter and beginning the process of gene transcription, linked in particular with the transport of calcium and phosphorus, including genes of osteocalcin, osteopontin or calbindin [8]. It should be mentioned that control of numerous genes involves also interaction of the nVDR-binding domain with specific sequences of DNA, termed the Vitamin D Response Element (VDRE) in promoter regions of specific genes. The process which precedes interaction of nVDR with VDRE involves the binding of the nuclear receptor to another receptor, the RXR (Retinoid X Receptor), formed due to conformational alterations. The heterodimer of VDR-RXR, of a transcription factor character, manifests the ability to interact with VDRE, and in this way participates in the control of numerous genes. Calcitriol is estimated to affect around 200 genes, with the reaction time at the genomic level reaching hours or even days $[3,6,7,9]$.
The active form of vitamin D is suggested to be capable of affecting target cells also using an alternate mechanism, through receptors situated in cell membrane caveoles. Response of the membrane Vitamin D Receptor (mVDR) employs variable signalling pathways, most probably reflecting various spatial conformations of ligands, which bind to domains of the two receptors (e.g., 6-s-cis for mVDR and 6-s-trans for nVDR). It should be added that nongenomic interactions of vitamin $\mathrm{D}$ develop much faster, in seconds or minutes $[8,10]$.

Role of adipocytes in metabolism of vitamin D. Reports of independent research centres indicate relationships between abnormalities in the metabolism of vitamin $\mathrm{D}$ and processes taking place in white adipose tissue of obese individuals. The phenomenon involves, first of all, alterations in expression of genes which code for the enzymes involved in the activation and turnover of the vitamin-resembling hormone [11].

Expression of the gene coding for 1 -hydroxylase (CYP27B1), the enzyme responsible for hydroxylation of $25(\mathrm{OH}) \mathrm{D}_{3}$ to $1,25(\mathrm{OH})_{2} \mathrm{D}_{3}$, was detected in the preadipocytes of mouse 3T3-L1 cell line, and in adipocytes in adipose tissue of Wistar rats [12]. Also, the expression was confirmed in preadipocytes and adipocytes of patients with the SimpsonGolabi-Behmel syndrome ${ }^{1}$ and in cells of human mammary glands [13-15]. Moreover, the presence of CYP24A1 gene product, i.e. the enzyme which catalyzes calcitriol turnover, was detected both in mouse adipocytes, 3T3-L1, and in human adipocytes [5]. Results of experimental studies indicate that in overweight individual's expression of genes coding for individual enzymes responsible for the metabolism of vitamin D underwent a reduction. Expression levels of genes coding for 25-hydroxylase (CYP2J2) and for 1a-hydroxylase (CYP27B1) were reduced by, respectively, $71 \%$ and $49 \%$ in subcutaneous adipose tissue of obese individuals, compared to individuals of reference Body Mass Index (BMI) (Fig. 1). It should be mentioned that in cases of a pronounced reduction in body weight, serum concentration of $25(\mathrm{OH}) \mathrm{D}_{3}$ became elevated by $27 \%$. Thus, dynamic alterations of the adipose tissue which accompany obesity or slimming down may affect the synthesis and serum concentration of vitamin D [16]. As mentioned above, the presence of vitamin D receptors was detected not only in organs responsible for osseous metabolism, but also in cells and tissues of other types. Expression of the VDR gene was confirmed in unilocular and multilocular adipocytes of mice and in the preadipocyte cell line 3T3-L1.

In the case of humans, few data of the range are available but there exist proofs that the expression of genes coding for vitamin $\mathrm{D}$ receptors may take place in human visceral and subcutaneous adipose tissue, in cell cultures of human preadipocytes and differentiated adipocytes (Fig. 1) [5, 14, 15]. Mature mammary gland adipocytes in humans were demonstrated to manifest the ability to bioactivate $25(\mathrm{OH})$ $\mathrm{D}_{3}$ and to convert it to $1,25(\mathrm{OH})_{2} \mathrm{D}_{3}$. This discovery suggests that adipocytes may affect the metabolism of vitamin $\mathrm{D}$ by their capacity to produce its active form which, subsequently, may be released locally to the microenvironment and microcirculation [5]. A similar role is ascribed to macrophages

1. Simpson-Golabi-Behmel syndrome - a genetically-conditioned syndrome of inborn errors, manifesting an extensive phenotypic variability. 
and cells of the connective tissue, the expansion of which can be noted in obesity, and in visceral obesity in particular. They provide potential for local hydroxylation and, in this way, they may affect the production of vitamin $\mathrm{D}[5,17]$.

Effect of vitamin D on adipocytes. Apart from the ability of adipocytes to influence the metabolism of vitamin $\mathrm{D}$, the potential is also indicated for the active involvement of vitamin $\mathrm{D}$ in processes taking place in adipose tissue. Studies in vitro suggest that $1,25(\mathrm{OH})_{2} \mathrm{D}_{3}$ inhibits adipogenesis and promotes apoptosis in adipocytes of 3T3-L1 mouse cell line $[18,19]$. Differentiation of adipose tissue cells remains under the control of induction involving certain transcription factors. The start of adipogenesis is accompanied by an increased expression of, among others, C/EBP protein, which binds to the nucleotide sequence of CCAAT (CCAAT Enhancer Binding Protein), Peroxisome Proliferator-Activated Receptor $\gamma($ PPAR $-\gamma)$ and Sterol Response Element Binding Protein 1 (SREBP1) and, therefore, compounds which participate in the development of adipose tissue. Assumptions exist that the active form of vitamin $\mathrm{D}$ (in relation to its dose and duration of action) manifests the ability to inhibit differentiation of preadipocytes 3T3-L1 by alteration of activity of the abovementioned adipogenic transcription factors. In a consequence, production of the so-called adipogenesis markers (including lipoprotein lipase) becomes reduced at individual stages of adipocyte differentiation [5]. In parallel, it was shown that $25(\mathrm{OH}) \mathrm{D}_{3}$ exerted no effect of the adipogenesis process in the mouse 3T3-L1 cell line [20].

In contrast to the inhibitory effects of vitamin $\mathrm{D}$ on the differentiation of mouse preadipocyte cell line (3T3-L1) in humans, the hormone activates the adipogenesis process (Fig. 1). In studies by Nimitphonga et al., on individuals with gigantic visceral obesity (subjected to surgery) mRNAs both for VDR and CYP27B1 were found to be easily detectable in visceral and subcutaneous adipose tissue. Also, an increased expression of CYP24A1 was detected in preadipocytes and newly-differentiated adipocytes in response to $1,25(\mathrm{OH})_{2} \mathrm{D}_{3}$. The results indicated that both forms of vitamin $\mathrm{D}$, i.e. $25(\mathrm{OH}) \mathrm{D}_{3}$ and $1,25(\mathrm{OH})_{2} \mathrm{D}_{3}$, show the ability to activate the differentiation process of human preadipocytes into mature adipocytes. In cell cultures exposed to one or another form of the vitamin-resembling hormone, a significant increase was detected in specific markers of adipogenesis, such as the level of mRNA for Fatty Acid Binding Protein 4 (FABP4), lipoprotein lipase and intensification of triglycerides accumulation. The data point to an active involvement of vitamin $\mathrm{D}$ in the metabolism of adipose tissue by stimulation of adipocyte differentiation. The probable mechanism of action manifested by the vitamin-resembling hormone is linked to the promotion of remodelling, involving substitution of mature adipocytes by new, insulin-sensitive cells of adipose tissue [20]. Results of the studies are consistent with reports of other centres performing experiments on animals. Mice with VDR knockout (VDR -/-) manifest lower amount of adipose tissue, hypotriglyceridaemia and lower concentration of total blood cholesterol, they are resistant to high energy diet which promotes obesity [21-23]. Analogously, mice with an over-expression of vitamin D receptor manifest signs of obesity even after exposed to low caloric diet [24].

In recent years, reports haven appeared on the favourable effect of vitamin D supplementation on the process of reduction in adipose tissue. Studies by Rosenblum et al. demonstrated that 16 weeks consumption of orange juice of normal or reduced caloric value, fortified with vitamin D $(100 \mathrm{IU}-2.5 \mu \mathrm{g})$ and calcium $(350 \mathrm{mg})$, promoted a significant decrease in the amount of visceral adipose tissue in a group of patients with excessive body weight (BMI within the range of $25-35 \mathrm{~kg} / \mathrm{m}^{2}$ ), compared to a control group consuming the juice not fortified with the components. In parallel, the supplementation failed to induce decreases in body weight of the participants [25]. Similar results were obtained by Zhu et el., pointing to the fact that 12 -week supplementation with vitamin D (125 UI - $3.125 \mu \mathrm{g})$ and a calcium (600 mg) preparation favourably effected a decrease in visceral adipose tissue in overweight persons and those with obesity but exerted no significant effect on their body weight [26]. However, it should be added that in certain investigations no relationship could be demonstrated between supplementation with the vitamin D and alterations in contents of adipose tissue $[27,28]$. Therefore, analyses within the scope remain equivocal, although they confirm a significant role of vitamin $\mathrm{D}$ in control of adipogenesis and of metabolic control both in humans and in animals.

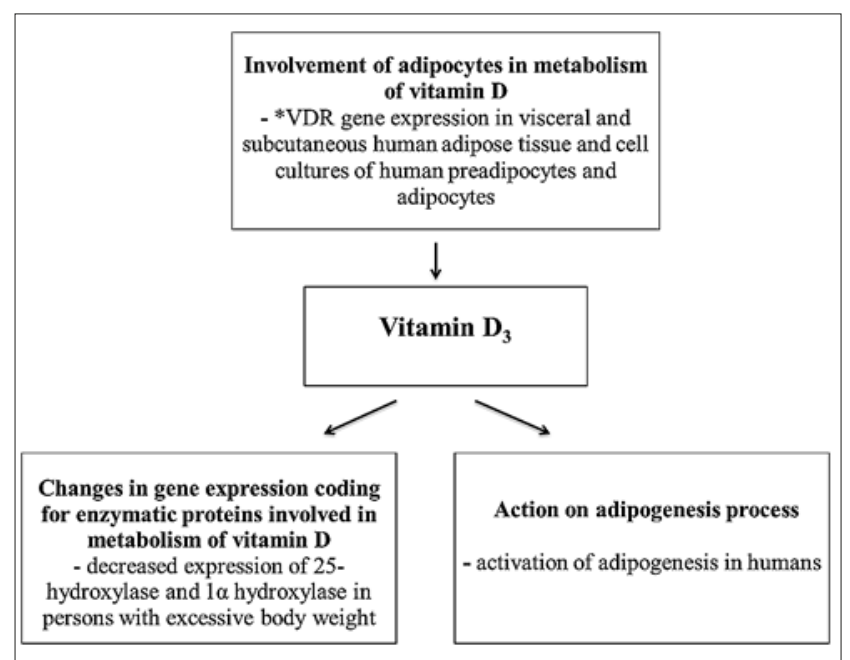

*VDR - Vitamin D Receptor

Figure 1. Metabolic relationships with involvement of vitamin $D_{3}$ Source: own modifications based on $[5,14,15,16,20]$

Causes of vitamin D deficiency in obesity. Visceral obesity or condition of excessive accumulation of adipose tissue exceeding physiological needs of the body, represents a growing problem for contemporary medicine. It is estimated that around $35 \%$ of the total human population manifests an excessive body weight (BMI exceeding $30 \mathrm{~kg} / \mathrm{m}^{2}$ ) and the trend manifests an increasing tendency [29]. Recently, as mentioned above, the attention of researchers is drawn to correlations between deficits of vitamin D manifestation of disturbances of metabolic character, including obesity $[11,30]$. Few potential theories can be distinguished which engage environmental factors, genetic variables and other conditioning which may be responsible for a decreased content of the component in sera of obese individuals [2].

Environmental factors. Among the principal factors which predispose obese individuals to lowered levels of vitamin D in blood (below $50 \mathrm{nmol} / \mathrm{L}$ ) is insufficient exposure to UVB sun rays, which are necessary for endogenous synthesis of the hormone. Depending on the geographic latitude, time of 
day and season, access of UVB photons to the skin surface may be restricted. In the autumn/winter seasons (among others, in most European countries) and, independently, in regions situated above $35^{\circ}$ of geographic latitude (in both hemispheres), the intensity of sun rays is negligible and insufficient to induce biosynthesis of vitamin $D[6,31]$. The element which restricts contact of the rays of sunlight with the skin involves also the clothing, which covers large areas of the body. To a significant extent, the problem affects obese individuals who are less prone to expose larger areas of their body to UVB rays than people with normal body weight (Tab. 1) [32]. On the other hand, the amount of synthesized vitamin $\mathrm{D}$ is directly related to the skin area exposed to rays of the sun, and one could expect that in obese individuals the process would manifest higher efficacy. However, analyses conducted by Wortsman et al. demonstrated that 24 hours after exposure to UVB radiation (at the dose of $27 \mathrm{~mJ} / \mathrm{cm}^{2}$ ) an increase 25-hydroxyvitamin D concentration in serum of persons with an excessive body weight was by $57 \%$ lower than in a group of normal body weight, with maintenance of similar 7-hydrocholesterol levels in all participants of the study [33]. Analyses of $1,25(\mathrm{OH})_{2} \mathrm{D}_{3}$ concentrations, conducted with using liquid chromatography in 17 individuals with gigantic obesity, subjected to bariatric surgery, were tenfold higher in subcutaneous abdominal adipose tissue than in sera [34]. Results of the studies provide evidence for a specific natural barrier in the form of subcutaneous adipose tissue, which forms a store of vitamin $\mathrm{D}$, sequesters it and impairs its transport to the circulation and the subsequent metabolic transformations [7]. In turn, studies by Sulistyoningrum et al. reported ethnic differences resulting from the type and contents of adipose cells. Compared to the European population, individuals originating from southern Asia manifested a higher content of visceral adipose tissue, which translated to lower blood concentrations of hydroxycholecalciferol in the investigated group. In cases of analyses (made in the linear regression model) evaluating total content of fat, subcutaneous and visceral adipose tissue in the participants of the study, only the latter manifested a negative correlation with serum concentrations of vitamin D [35]. It is worth noting that in the Norwegian cross-sectional cohort HUNT Study, in 2,000 persons a low serum concentration of $25(\mathrm{OH}) \mathrm{D}$ (below $50 \mathrm{nmol} / \mathrm{L}$ ) was found to manifest correlation with higher frequency of obesity, defined on the basis of BMI [36].

A significant factor affecting the vitamin $\mathrm{D}$ level in the blood of overweight individuals involved the supply of the nutrient in diet. Low consumption of products naturally rich in vitamin $\mathrm{D}$, such as fish, milk, butter and some mushrooms (e.g. chanterelle), results in daily food rations frequently not covering the recommended norms of its consumption (Tab. 1) [11]. The amount of consumed vitamin D-containing products manifests a negative correlation with weight of body fat, incidence of hypertension or glucose intolerance [37]. It should be mentioned that the highest blood concentrations of the vitamin among European nations were detected in Norwegians, manifesting high consumption of sea fish. Studies conducted on 19,000 Norwegians documented, both in men and women, a reciprocal and direct correlation between BMI and supply of vitamin D with diet [38]. Moreover, a specific manner of nutrition, for example, monotonous types of diet characterized by highly repetitive meals may also promote development of deficits in supply of the vitamin in the examined group [39].
Genetic conditioning. Analyses of a genetic nature provide the opportunity to link modifications in genome structure with epidemiological data. It has been pointed out that alterations in nucleotide sequence (polymorphisms and mutations) within VDR gene result in biological effects, including manifestation of obesity. Polymorphisms related to single nucleotides, in particular those located close to the $3^{\prime} \mathrm{UTR}$ terminus, represent sites commonly recognized by restriction enzymes (including FokI, BsmI, ApaI or TaqI). The presence or absence of individual sequences provides the source of polymorphism in the gene of vitamin D receptor (Restriction Fragments Length Polymorphism - RFLP) [30]. In studies conducted on a group of Latino women, a FokI polymorphism of VDR gene with the 'ff' genotype was found to be linked to an increased Waist to Hip Ratio (WHR) index among participants, which indirectly pointed to the central distribution of adipose tissue, associated with an unfavorable metabolic profile [40]. Reports by other research centres show that BsmI polymorphism of vitamin D receptor ('BB' genotype) predisposes to higher body weight and elevated BMI index (Tab. 1) [30].

Clone of genomic DNA for 24-hydroxylase (the enzyme which catalyzes turnover of $1,25(\mathrm{OH})_{2} \mathrm{D}_{3}$ ) was isolated from the 20th chromosome of the human genome. In parallel, proof was presented that the gene variant located in band 13 of the chromosome long arm represents a risk factor for deficiency of vitamin D. Mutation of the complex GNAS1 locus (20q13) was found to be linked to manifestation of pseudohypoparathyroidism, complicated by the manifestation of obesity. Additionally, the results of independent studies indicate a few various genes responsible for the induction of obesity are located just in this region of the chromosome [41-43].

Apolipoprotein E (ApoE) represents a significant factor linked to metabolism and to the concentration of vitamin D. The molecule represents a component of VLDL and HDL cholesterol and it plays a significant role in the transport and metabolism of lipids. The ApoE gene, located on chromosome 19 (19q13.2), manifests a pronounced polymorphism. Allele $\varepsilon 4$ of the ApoE gene represents a commonly known risk factor of multifactorial conditioned diseases, such as cardiovascular disturbances or diabetes mellitus type 2. Among others, the gene conditions higher blood concentrations of total cholesterol or of low density lipoproteins. In contrast to the 'pathogenic' $\varepsilon 4$ allele, the $\varepsilon 2$ allele manifests a reciprocal effect as it seems to protect against the development of cardiovascular diseases and to promote longevity [44-46]. However, a report by a group of German scientists on the association of the $\varepsilon 4$ allele with elevated levels of vitamin D in blood indicated a strict link between polymorphism of ApoE and metabolism of the above-mentioned vitamin. In parallel, until now, the negatively-regarded allel $\varepsilon 4$ proved to represent a protective factor, preventing against deficiency of vitamin D (Tab. 1). The studies were of a pilot character since they were performed on a relatively small group of patients with metabolic syndrome (MetS, 93 individuals), and on a larger general population (699). The observed mean levels of $25(\mathrm{OH}) \mathrm{D}_{3}$ amounted to, respectively, 47.6 $\mathrm{nmol} / \mathrm{L}$ in patients with MetS and $44.2 \mathrm{nmol} / \mathrm{L}$ in members of the general population. It should be added that $32 \%$ of the patients with metabolic syndrome and $28 \%$ of the general population carried at least a single $\varepsilon 4$ allel. This allele was linked to higher blood concentrations of $25(\mathrm{OH}) \mathrm{D}_{3}$ compared to persons not carrying the genetic variant [47]. The studies 
require broader population analyses due to the manifestation of distinctions in deficiency of vitamin $\mathrm{D}$, reflecting, among others, geographic position and season of the year, but they indicate a potential role of genetic polymorphisms in the conditioning of serum vitamin D concentrations.

To-date, no unequivocal solution has been forthcoming on the cause and effect relationships predisposing to hypovitaminosis $\mathrm{D}$ in conditions accompanied with an excessive accumulation of adipocytes. An attempt to resolve the problem involved experiments undertaken by Vimaleswaran et al., who conducted bi-directional genetic analyses with randomization involving 21 cohorts, i.e. a total of 42,000 individuals from the UK, Germany, Sweden, Finland, Canada and USA. They encompassed determination of 12 Single Nucleotide Polymorphisms (SNP) responsible for the size of the BMI, and 4 polymorphisms linked to serum concentration of $25(\mathrm{OH}) \mathrm{D}_{3}$. Relationships were documented between an increase in BMI and a reduction in serum vitamin $\mathrm{D}$ concentration. An increase of BMI by every $1 \mathrm{~kg} / \mathrm{m}^{2}$ resulted in a decrease in concentration of 25 -hydroxycholecalciferol by $1.15 \%$. On the other hand, the genetic predispositions which determined the level of vitamin D were not found to correlate with BMI [48]. Thus, the reports pointed to a uni-directional relationship between overweight condition, obesity and hypovitaminosis D. However, several unknown parameters remain to be explained, among others related to bioavailability of the alimentary component, which justifies the necessity to continue studies on this aspect [49].

Other causes predisposing obese individuals to a deficiency of vitamin $\mathrm{D}$ include disturbances in intestinal absorption of the alimentary component. Among others, administration of drugs which normalize lipid metabolism, frequently observed in individuals with excessive body weight, results in inhibited absorption of the vitamin-resembling hormone from the alimentary tract. Accompanying diseases, particularly within the liver and kidneys (organs which actively participate in metabolic turnover of the vitamin) should be taken as an indication to consider the appropriate supplementation. Also, disturbances of a gastroenterologic background (e.g. Lesniowski-Crohn disease) or use of drugs which intensify catabolism of vitamin D (e.g. glycocorticosteroids) may result in its low serum concentration (Tab. 1) [1].

Independent factors which affect the concentration of vitamin $\mathrm{D}$ include age and the melanin content in the skin (Tab. 1). Progressing age was found to reduce dermal synthesis of vitamin $\mathrm{D}$, as well as the amount of 7-dehydrocholesterol required for its production. In persons of an advanced age, the phenomenon is thought to represent the physiological consequence of senescence [2]. Nevertheless, abnormalities in serum concentration of vitamin D are also encountered in other groups, including children and youths. Results of experimental studies conducted on heterogeneous age groups point to the manifestation of deficiencies of the vitamin both in young persons (10 - 18 years of age) and in older individuals (over 60 years of age) [50-52]. In turn, melanin, the compound responsible for skin pigmentation, effectively blocks synthesis of vitamin D in individuals with a dark complexion. Studies conducted by Clemens et al. indicate a reduction (even tenfold) of this process in humans with an increased skin pigmentation [53]. In view of the tendency of aging in most societies of the world, persons particularly exposed to deficiency of vitamin $\mathrm{D}$ will include obese individuals at advanced age, particularly those of with dark complexion.
Table 1. Variables affecting synthesis and concentration of vitamin D in blood

\begin{tabular}{lll}
\hline \multicolumn{3}{c}{ Types of factors } \\
\hline Environmental & Genetic & Other \\
\hline - Insufficient exposure & - Polymorphisms of & - Disturbances in \\
to UVB radiation: & gene coding for & intestinal absorption: \\
- geographic latitude & vitamin D receptor & - some drugs intake \\
- season of year/time & - Gene located on & (e.g. statins, \\
of day & chromosome 20 & glycocorticoids) \\
- clothing covering & (20q13) as a risk factor & - co-morbidities of \\
large areas of body & for deficiency of & gastroenterologic \\
- Supply of vitamin D in & vitamin D & background \\
diet & Polymorphism of & - Diseases of liver, \\
& ApoE - allele $\varepsilon 4$ as a & kidneys \\
& potential protective & - Age \\
& factor & - Content of melanin in \\
& & skin \\
\hline
\end{tabular}

Source: own modifications based on $[1,2,6,11,30-32,37,41-43,47,53]$

\section{CONCLUSIONS}

The correct concentration of vitamin D is of key significance in several diseases, including obesity, and particularly its visceral type. An excessive body weight is thought to represent a significant determinant of a reduced vitamin $\mathrm{D}$ concentration in serum. Due to its high metabolic activity, visceral adipose tissue promotes sequestration and alterations in turnover of the vitamin-resembling hormone. In addition, reports are available indicating the effects of vitamin $\mathrm{D}$ on the adipogenesis process. The data prove that interrelationships exist between calcitriol and adipose tissue, the excess of which is noted in obesity $[7,20]$. Beyond doubt, low serum concentrations of $25(\mathrm{OH}) \mathrm{D}_{3}$ predispose to manifestation of several disturbances, including hyperglycaemia, hyperinsulinaemia, higher levels of the HOMA-IR index or hypertriglyceridaemia $[7,51]$. In a meta-analysis of relationships between concentration of vitamin $\mathrm{D}$ and risk for development of metabolic syndrome, diabetes mellitus type 2 and insulin resistance, high levels of the vitamin-resembling hormone were found to manifest a negative correlation with manifestation of the above-mentioned disorders [54].

Among the factors which determine serum concentration of vitamin $\mathrm{D}$, environmental, genetic conditioning is mentioned, as well as other factors which may participate in the metabolism of the compound [30]. Depending on geographic position, time of day and the season of the year, dietetic supply, age, coexisting diseases and melanin content in the skin, blood concentrations of vitamin D may vary and may differ from values regarded to be a reference.

An important variable involves also modifications of a genetic nature. Depending on the type of genetic variant (genotype), the presence of personal predispositions is also noted to increases in body weight or in content of adipose tissue. Not less significant determinants involve also modifications in the activation and turnover of the vitamin-resembling hormone. Expression of vitamin D receptor and of enzymes catalyzing vitamin $\mathrm{D}$ turnover take place in preadipocytes and in adipocytes of humans, while an excessive body weight resulting from a high content of adipose tissue promotes the development of metabolic disorders $[2,11,30]$.

Taking the above into consideration, several independent factors exist which may affect the status of vitamin $D$ in obesity. Care for elimination of the factors which promote 
deficiencies, including assurance of an appropriate supply of the vitamin-resembling hormone (through sun baths, application of a diet rich in ergo- and cholecalciferol and supplementation) is particularly essential in obese persons in whom degree of adiposity correlates with reduced concentrations of this vitamin in blood.

\section{REFERENCES}

1. Napiórkowska L, Franek E. Rola oznaczania witaminy D w praktyce klinicznej. Chor Serca Naczyn. 2009; 6(4): 203-210 (in Polish).

2. Kosińska J, Billing-Marczak K, Krotkiewski M. Nowe nieznane funkcje witaminy D. Med Rodz. 2008; 2: 34-37 (in Polish).

3. Cannoll JJ, Hollis BW. Use of vitamin D in clinical practice. Altern Med Rev. 2008; 13(1): 6-20.

4. Holick MF, Binkley NC, Bischoff-Ferrari HA, Gordon CM, Hanley DA, Heaney RP, et al. Evaluation, treatment, and prevention of vitamin D deficiency: an Endocrine Society clinical practice guideline. J Clin Endocrinol Metab. 2011; 96(7): 1911-1930.

5. Ding C, Gao D, Wilding J, Trayhurn P, Bing C. Vitamin signaling in adipose tissue. Brit J Nutr. 2012; 108(11): 1915-1923.

6. Tukaj C. Właściwy poziom witaminy D warunkiem zachowania zdrowia. Post Hig Med Dosw. 2008; 62: 502-510 (in Polish).

7. Wang C. Role of vitamin D in cardiometabolic diseases. J Diabetes Resch. 2013. ID 243934, 10 pages.

8. Pełczyńska M, Jaroszewicz I, Świtalska M, Opolski A. Właściwości biologiczne kalcytriolu i jego nowych analogów - potencjalne zastosowania terapeutyczne. Postepy Hig Med Dosw. 2005; 59: 129-139 (in Polish).

9. Haussler MR, Whitfield GK, Kaneko I, Haussler CA, Hsieh D, Hsieh JC, et al. Molecular mechanisms of vitamin D action. Calcif Tissue Int. 2013; 92(2): 77-98.

10. Norman AW. Minireview: vitamin D receptor: new assignments for an already busy receptor. Endocrinology. 2006; 147(12): 5542-5548.

11. Vanlint S. Vitamin D and obesity. Nutrients. 2013; 5: 949-956.

12. Li J, Byrne ME, Chang E, Jiang Y, Donkin SS, Buhman KK, et al. lalpha,25-dihydroxyvitamin D hydroxylase in adipocytes. J Steroid Biochem Mol Biol. 2008; 112(1-3): 122-126.

13. Ching S, Kashinkunti S, Niehaus MD, Zinser GM. Mammary adipocytes bioactivate 25 -hydroxyvitamin $\mathrm{D}$ and signal via vitamin $\mathrm{D}$ receptor, modulating mammary epithelial cell growth. J Cell Biochem. 2011; 112(11): 3393-3405.

14. O'Hara A, Lim FL, Mazzatti DJ, Trayhurn P. Microarray analysis identifies matrix metalloproteinases (MMPs) as key genes whose expression is up-regulated in human adipocytes by macrophageconditioned medium. Pflugers Arch. 2009; 458(6): 1103-1114.

15. Trayhurn P, O'Hara A, Bing C. Interrogation of microarray datasets indicates that macrophage-secreted factors stimulate the expression of genes associated with vitamin D metabolism (VDR and CYP27B1) in human adipocytes. Adipobiology. 2011; 3: 29-34.

16. Wamberg L, Christiansen T, Paulsen SK, Fisker S, Rask P, Rejnmark $\mathrm{L}$, et al. Expression of vitamin D-metabolizing enzymes in human adipose tissue - the effect of obesity and diet-induced weight loss. Int J Obes. 2013; 37(5): 651-657.

17. Bikle D. Extra renal synthesis of 1,25-dihydroksyvitamin D and its health implications. Clin Rev Bone Mineral Metab. 2009; 7(2): 114-125.

18. Kong J, Li YC. Molecular mechanism of 1,25-dihydroxyvitamin D3 inhibition of adipogenesis in 3T3-L1 cells. Am J Physiol Endocrinol Metab. 2006; 290(5): 916-924.

19. Sergeev I. 1,25-dihydroxyvitamin D3 induces $\mathrm{Ca}^{2+}$ - mediated apoptosis in adipocytes via activation of calpain and caspase-12. Biochem Biophys Res Commun. 2009; 384(1): 18-21.

20. Nimitphong H, Holick MF, Fried SK, Lee MJ. 25-hydroxyvitamin D3 and 1,25-dihydroxyvitamin D3 promote the differentiation of human subcutaneous preadipocytes. Plos One. 2012; 7(12): e52171. doi: 10.1371/ journal.pone.0052171

21. Wong KE, Szeto FL, Zhang W, Ye H, Kong J, Zhang Z, et al. Involvement of the vitamin D receptor in energy metabolism: regulation of uncoupling proteins. Am J Physiol Endocrinol Metab. 2009; 296(4): E820-E828.

22. Narvaez CJ, Matthews D, Broun E, Chan M, Welsh J. Lean phenotype and resistance to diet-induced obesity in vitamin $D$ receptor knockout mice correlates with induction of uncoupling protein-1 in white adipose tissue. Endocrinology. 2009; 150(2): 651-661.
23. Weber K, Erben RG. Differences in triglyceride and cholesterol metabolism and resistance to obesity in male and female vitamin D receptor knockout mice. J Anim Physiol Anim Nutr. 2013; 97(4): 675-683.

24. Wong KE, Kong J, Zhang W, Szeto FL, Ye H, Deb DK, et al. Targeted expression of human vitamin $\mathrm{D}$ receptor in adipocytes decreases energy expenditure and induces obesity in mice. J Biol Chem. 2011; 286(39): 33804-33810.

25. Rosenblum JL, Castro VM, Moore CE, Kaplan LM. Calcium and vitamin $\mathrm{D}$ supplementation is associated with decreased abdominal visceral adipose tissue in overweight and obese adults. Am J Clin Nutr. 2012; 95: 101-108.

26. Zhu W, Cai D, Wang Y, Lin N, Hu Q, Qi Y, et al. Calcium plus vitamin $\mathrm{D}_{3}$ supplementation facilitated fat loss in overweight and obese college students with very-low calcium consumption: a randomized controlled trial. Nutr J. 2013; 12: 8. doi: 10.1186/1475-2891-12-8.

27. Wamberg L, Kampmann U, Stodkilde-Jorgensen H, Rejnmark L, Pedersen SB, Richelsen B. Effects of vitamin D supplementation on body fat accumulation, inflammation, and metabolic risk factors in obese adults with low vitamin D levels - results from a randomized trial. Eur J Intern Med. 2013; 24(7): 644-649.

28. Sneve M, Figenschau Y, Jorde R. Supplementation with cholecalciferol does not result in weight reduction in overweight and obese subjects. Eur J Endocrinol. 2008; 159: 675-684.

29. World Health Organization: Obesity. Geneva, WHO. 2008. http://www. who.int/topics/obesity/en (access: 2014.02.03).

30. Luong KVQ, Nguyen LTH. Vitamin D and obesity. Med Chem. 2012; 2: 011-019.

31. Burgaz A, Akesson A, Oster A, Michaelsson K, Wolk A. Associations of diet, supplement use and ultraviolet $B$ radiation exposure with vitamin D status in Swedish women during winter. Am J Clin Natur. 2007; 86(5): 1399-1404.

32. Kull M, Kallikorm R, Lember M. Body mass index determines sunbathing habits: Implications on vitamin D levels. Intern Med J. 2009; 39(4): 256-258.

33. Wortsman J, Matsuoka LY, Chen TC, Lu Z, Holick MF. Decreased bioavailability of vitamin D in obesity. Am J Clin Nutr. 2000; 72(3): 690-693.

34. Bulm M, Dolnikowski G, Seyoum E, Harris SS, Booth SL, Peterson J, et al. Vitamin D(3) in fat tissue. Endocrine. 2008; 33(1): 90-94.

35. Sulistyoningrum DC, Green TJ, Lear SA, Devlin AM, Muller M. Ethnicspecific differences in vitamin D status is associated with adiposity. Plos One. 2012; 7(8): e43159. doi: 10.1371/journal.pone.0043159.

36. Mai XM, Chen Y, Camargo CA Jr, Langhammer A. Cross-sectional and prospective cohort study of serum 25-hydroxyvitamin D level and obesity in adults: the HUNT study. Am J Epidemiol. 2012; 175(10): 1029-1036.

37. Al-Daghri NM, Alkharfy KM, Al-Othman A, Yakout SM, Al-Saleh Y, Fouda M, et al. Effect of non-pharmacologic vitamin D status correction on circulating bone markers in healthy overweight and obese. Molecules. 2013; 18(9): 10671-10680.

38. Kamycheva E, Joakimsen RM, Jorde R. Intakes of calcium and vitamin $\mathrm{D}$ predict body mass index in the population of Northern Norway. J Nutr. 2003; 133(1): 102-106.

39. Alpert PT, Shaikh U. The effects of vitamin D deficiency and insufficiency on the endocrine and paracrine system. Biol Res Nurs. 2007; 9(2): 117-129.

40. Sweeney C, Murtaugh MA, Baumgartner KB, Byers T, Giuliano AR, Herrick JS, et al. Insulin-like growth factor pathway polymorphisms associated with body size in Hispanic and non-Hispanic white women. Cancer Epidemiol Biomarkers Prev. 2005; 14(7): 1802-1809.

41. Bastepe M, Lane AH, Juppner H. Paternal uniparental isodisomy of chromosome 20q-and the resulting changes in GNAS1 methylation as a plausible cause of pseudohypoparathyroidism. Am J Hum Genet. 2001; 68(5): 1283-1289.

42. Lee JH, Reed DR, Li WD, Xu W, Joo EJ, Kilker RL, et al. Genome scan for human obesity and linkage to markers in 20q13. Am J Hum Genet. 1999; 64(1): 196-209.

43. Wang TJ, Zhang F, Richards JB, Kestenbaum B, van Meurs JB, Berry $\mathrm{D}$, et al. Common genetic determinants of vitamin $\mathrm{D}$ insufficiency: a genome-wide association study. Lancet. 2010; 376: 180-188.

44. Eisenberg DT, Kuzawa CW, Hayes MG. Worldwide allele frequencies of the human apoliprotein E (APOE) gene: climate, local adaptations and evolutionary history. Am J Phys Anthropol. 2010; 143(1): 100-111.

45. Ferreira DC, Costa TF, Aguiar SL, Marques AR, Ramos SA, Gomes KB, et al. Association of apolipoprotein E polymorphisms and metabolic 
syndrome in subjects with extreme obesity. Clin Chim Acta. 2011; 412(17-18): 1559-1562.

46. Luong KVQ, Nguyen LTH. The beneficial role of vitamin D in obesity: possible genetic and cell signaling mechanisms. Nutrition J. 2013; 12(89). doi: $10.1186 / 1475-2891-12-89$.

47. Huebbe P, Nebel A, Siegert S, Moehring J, Boesch-Saadatmandi C, Most $\mathrm{E}$, et al. APOE $\varepsilon 4$ is associated with higher vitamin D levels in targeted replacement mice and humans. FASEB J. 2011; 25(9): 3262-3270.

48. Vimaleswaran KS, Berry DJ, Lu C, Tikkanen E, Pilz S, Hiraki LT, et al. Causal relationship between obesity and vitamin D status: Bi-directional mendelian randomization analysis of multiple cohorts. PLOS Medicine. 2013; 10(2): e1001383. doi:10.1371/journal.pmed.1001383.

49. Kienreich K, Tomaschitz A, Verheyen N, Pieber T, Gaksch M, Grübler $\mathrm{MR}$, et al. Vitamin D and cardiovascular disease. Nutrients. 2013; 5(8): 3005-3021.
50. Kardas F, Kendirci M, Kurtoglu S. Cardiometabolic risk factors related to vitamin $\mathrm{D}$ and adiponectin in obese children and adolescents. Int J Endocrinol. 2013. doi: 10.1155/2013/503270.

51. Garanty-Bogacka B, Syrenicz M, Goral J, Krupa B, Syrenicz J, Walczak $\mathrm{M}$, et al. Serum 25-hydroxyvitamin D (25-OH-D) in obese adolescents. Pol J Endocrinol. 2011; 62(6): 506-511.

52. Park HY, Lim YH, Kim JH, Bae S, Oh SY, Hong JC. Association of serum 25-hydroxyvitamin D levels with markers for metabolic syndrome in the elderly: A repeated measure analysis. J Korean Med Sci. 2012; 27(6): 653-660.

53. Clemens TL, Adams JS, Henderson SL, Holick MF. Increased skin pigment reduces the capacity of skin to synthesis vitamin D3. Lancet. 1982; 1: 74-76.

54. Khan H, Kunutsor S, Franco OH, Chowdhury R. Vitamin D, type 2 diabetes and other metabolic outcomes: a systematic review and meta-analysis of prospective studies. Proc Nutr Soc. 2013; 72(1): 89-97. 